\title{
Can Ethical Political Leadership Restore Public Trust in Political Leaders?
}

\author{
N. A. Mozumder ${ }^{1}$ (1D
}

Accepted: 7 June 2021 / Published online: 10 August 2021

(c) The Author(s) 2021

\begin{abstract}
This article presents findings from a qualitative study (via in-depth interviews with 121 local political leaders from 65 local authorities in the UK) that aims to understand how ethical leadership practices can restore public trust in political leaders. The study finds that being a moral person, an ethical political leader sets good examples of behaviour, sets the tone at the top and challenges those who do not behave ethically, as well as encourages, supports and rewards those who perform and conduct themselves well. As a result, the level of public trust in political leaders is likely to increase gradually.
\end{abstract}

Keywords Ethical political leadership · Local government · Trust

\section{Introduction}

Recently there have been a number of high-profile perceived unethical leadership behaviour and practices. These have affected the public's trust in political leaders and government globally (see, Elderman Trust Barometer, 2019b). Trust in political leaders and government is at a low level although trust in government is considered as an indispensable for the effective functioning of democracy. The decline of public trust in political leaders is well documented. The study has also found evidence in support of the decline.

Regardless of the current level and direction of the public's trust in political leaders, the key questions are as follows: How to restore the public's trust? Can ethical political leadership restore public trust in political leaders? How? In order to address these very closely interconnected questions, local political leaders across the UK were interviewed. The results of these interviews were analysed and presented in the context of the regulatory framework, and being a moral person and a moral leader. The key finding of this study is that the remedies for the distrust lie largely in the

\section{N. A. Mozumder}

nalammozumder@gmail.com

1 University of Bristol, Bristol BS8 1TH, UK 
hands of political leaders themselves. Trust can be gradually restored to a reasonable level when words and actions accord with one another - telling the truth, keeping promises and engaging with the community.

Over the decade, a growing body of research (e.g., Beshi \& Kaur, 2020; Mozumder, 2018; Rose \& Wessels, 2019) has recognised the significant contributions of ethical leadership practices in enhancing public trust in government. Despite the rapid growth of ethical leadership research there remain gaps in the relevant literature. First, the context of most previous studies has been managerial ethical leadership in public organisations. Political leaders were excluded. To fill this gap, the context of the study is ethical political leadership in local government. Political leaders work in a different context (Morrell \& Hartley, 2006a, b). Local politicians have direct contact with the public who elect them. People elect political leaders based on their manifestos, and trust them to fulfil their promises and act in a way that serves the public interest. Party politics, political interests and rivalry create special challenges (and new research opportunities) for the practice of ethical political leadership in local government. Second, leadership context is a major factor that affects leadership processes and outcomes (Osborn et al., 2002). There is a lack of empirical research on ethical political leadership in UK local government (See, $\mathrm{Ng} \&$ Feldman, 2015). This study aims to fill this void by attempting to contextualise ethical political leadership in UK local government. The current socio-political factors for the UK politics, such as Brexit which has created a division in the society as well as in politics across the UK, provide us with a context for an interesting case study. Moreover, the conflictual political environment, hierarchical (multi-level) leadership and electoral authority in the local government may implicate leaders in political interest seeking. Third, a number of studies (e.g., Hassan, 2015; Mozumder, 2018) have found evidence in support of a positive relationship between value-based leadership and leadership outcomes in public organisations. Nonetheless, how ethical political leaders influence positive outcomes (e.g., public trust) is still understudied. This study aims to fill this void by gaining a better understanding of the psychological process by which ethical political leaders influence public trust.

Considering the hierarchical structure of party politics, this study is based on the premise that political leadership is a multilevel phenomenon. All levels of ethical political leadership matter. In a democracy, each local councillor is a leader of the community as its elected representative. Councillors are likely to act as ethical role models because of their proximity to the community. The party group leaders and whips set the tone at the top and influence their followers to act ethically (or unethically). Drawing on social learning theory (Bandura, 1977, 1986) and social exchange theory (Blau, 1964), the study maintains that the party political leadership process cascades or trickles down from party leaders to local leaders and then to the community.

Social learning theory (SLT) and social exchange theory (SET) are cognitive and behavioral approaches that have provided theoretical framework for building and maintaining trusting relationships between social actors. SLT can be broadly understood as a social behavioural approach that underlines the reciprocal interaction between cognitive, behavioral and environmental determinants of human behaviour and actions (Bandura, 1977). SET posits that the interaction of people with others 
based on an assessment of the costs and benefits (intrinsic and extrinsic) of such interactions (Blau, 1964). Reciprocity is a crucial factor to participation behavior. Ethical leaders may influence followers through social exchange processes based on the norm of reciprocity; followers feel obligated to reciprocate helpful and fair treatments (Mozumder, 2018). Both SLT and SET have focused on the social structures created by repeated social interactions (and exchanges) and the ways in which these social structures both restrain and permit social actors to gain, exercise and maintain power and influence. Within the social influence and social exchange processes commitment, fairness and collective action can influence trusting relationships. Previous research proved and explained this relationship. For example, from a practical perspective, the findings of Mozumder (2018) supports the notion of trust as the axis on which socio-emotional relationships revolve. Therefore, following the SLT and SET logic, leaders are expected to influence followers' behaviour by demonstrating ethically appropriate behaviour and through socio-emotional exchange process based on trust.

The rest of the article is structured as follows. The next section elaborates on the theoretical background by conceptualising key components of ethical political leadership and trust, and setting up the context of the study. The research methodology is discussed in the following section. The next section analyses and presents the findings, and how they address the original research questions. In the following section implications of the findings are discussed. Finally, concluding remarks are offered.

\section{Ethical Political Leadership and Trust in Political Leaders}

Dinh et al. (2014) and Van Wart (2013a, b) highlighted the diversity of leadership literature. Leadership has been defined from different perspectives based on the purpose of the study, context and the underlying motivational process. For example, Brown et al. (2005, p. 120) defined ethical leadership as "the demonstration of normatively appropriate conduct through personal actions and interpersonal relationships, and the promotion of such conduct to followers through two-way communication, reinforcement, and decision making.' Brown and his colleagues left the term 'normatively appropriate' vague because they considered that appropriate conduct is to some extent context dependent. This assumption is likely to be correct, yet without core moral reference points we can find reasons for justifying almost any of our intentions, actions or outcomes. March and Olsen (2004) emphasizes on the rules (logic) of appropriateness in the context of formally organized political institutions and democratic political orders. The minimisation of ethics to autonomy in a socio-political context could tear the heart out of ethics. There are various, more or less widely shared core moral values and virtues, combined with deontological and consequentialist elements, such as truthfulness, trustworthiness, keeping promises, which may be of normative significance. Core moral senses of terms such as truthfulness, which seem to be easily understood by most people in different societies and cultures, may serve as norms, helping us to assess and eventually guide our intentions and actions. 
Honesty, integrity, fairness, trustworthiness and concern for others are the core elements of many emerging leadership theories such as authentic (Luthans \& Avolio, 2003), Spiritual (Fry, 2003), and ethical (Brown et al., 2005) leadership. Brown and his colleagues refer these characteristics as a moral person aspect of ethical leadership. The other aspect they refer to is that of moral manager, who sets the tone at the top, acts as a role model and influences follower's behaviour through socio-emotional exchange process. There are significant overlaps between the terms manager and leader in organisational settings. However, in political context the term leader seems more appropriate because elected councillors are not responsible for day to day management of the council business. Being a moral person first, a moral leader influences the moral conducts of their followers.

This study takes a triple-pillar approach to ethical leadership, examining ethical leadership practices in the context of code of conduct (regulatory framework), being a moral person and being a moral leader. Although some occasionally makes a distinction, the terms ethics and morality are used interchangeably because morality can refer to personal, social and religious values, code of conduct or social mores (or norms) from a society, or a standard (goodness and rightness) that is believed, accepted and applied by an individual. Public leadership studies (e.g., Downe et al., 2013; Mozumder, 2018) have begun to find a connection between value-based leadership practices and codes of conduct and their effect on followers' behaviors and cognitions. Regulatory (codified) framework establishes how a government and its society function and enforces the behaviors and actions individuals are expected to follow, while ethics suggest what individuals ought to follow. Ethical leadership comes from within individual's moral sense.

Although the phenomenon of ethical leadership has been studied more than fifteen years, both theoretically and empirically (e.g., Brown et al., 2005; Hassan et al., 2014; Mozumder, 2018), there remain gaps in our knowledge of how the ethical leadership process actually operates in a political context (Leach \& Wilson, 2002). Morrell and Hartley (2006a, p. 484) define political leaders as: “i) democratically elected ii) representatives who iii) are vulnerable to deselection, and iv) operate within, as well as influence a constitutional and legal framework." This definition illustrates how elected political leaders differ from other leaders such as informal political leaders, despots, as well as from private-, public- and voluntary-sector leaders, who do not have a similar mandate. This distinction has not been adequately addressed in the literature. The key question is whether ethics has an essential role to play in political leadership.

From Socrates, Plato and Aristotle to Machiavelli, Hobbes and Kant, political philosophers and scientists have elaborated their thoughts about the relationship between ethics and politics. Both dirty hands (see, Walzer, 1973) and moral dilemma challenge the idea that moral values are absolute. The question is whether we require extremely moralized politics, tending to utopianism, or extremely politicised morality, tending to drop authentic morality altogether. We need to find a balance by determining the core components of an ethical standard; understanding this could help us minimise the tensions between morality and politics.

In a democracy, ethical political leadership can be conceptualised as a sociopolitical process where the leaders are duly elected, guided by principles, motivated 
by public values and trust, and act within the socio-legal framework to impact the lives of citizens. Public values (or public interests) and trust are two key components of ethical political leadership. Trust is defined as the "psychological state comprising the intention to accept vulnerability based upon positive expectations of the intentions or behaviour of another' (Rousseau et al., 1998, p. 395). Trust in political leaders refers to the level of confidence citizens have in their elected representatives to act appropriately and honestly in the public interest rather than from self-interest (see, Citrin \& Stoker, 2018). Trust in political leaders is vital for the effective functioning of a democratic government (see, Beerbohm, 2015). Democracy is an important example of the principal-agent relationship, where the public (principal) entrust a relatively small number of representatives (agents) with powers to govern them. Yet the public should not abandon scepticism or have blind faith in political agents. In no political system is it prudent to trust completely. Appropriate mechanisms for checks and balances are essential for effective functioning of democracy.

In response to public concerns to improve the ethical standards of political leaders, the Committee on Standards in Public Life, which was established in 1994, is responsible for promoting the seven principles of public life: selflessness, integrity, objectivity, accountability, openness, honesty, and leadership - commonly known as the Nolan Principles. Under section 27 of the Localism Act 2011, each local authority must adopt a code of conduct against which councillors' conduct may be assessed.

The code of conduct is not an alternative to moral values, although a lack of regulatory framework may increase the risk of things going from bad to worse. In its 20th report on local government ethical standards, the Committee on Standards in Public Life (2019) concluded that the current framework is conducive to promoting and maintaining the standards expected by the public. Yet, public trust in political leaders is declining (Elderman Trust Barometer, 2019a). Therefore, given the changing historical, economic, social, political and legal context of democratic government, this is a particularly appropriate time to study ethical political leadership in the UK local government.

\section{Methodology}

In response to the call for more detailed qualitative research on ethical leadership (Hassan, 2015) a qualitative approach (Flick, 2002) is employed in this study. The study of ethical leadership in political context is particularly well suited for qualitative analyses because of the multidisciplinary nature of the field. Moreover, the study of leadership is context dependent. The qualitative approach helps illuminate the phenomenon through the perceptions of the political leaders, generating insights into their motives and actions.

Data were collected in 2019 mainly via in-depth interviews with multiple informants, including elected council leaders, leaders of party groups, mayors, whips, cabinet members, chairs of committees (e.g., standard committee, overview and scrutiny committee) and councillors without portfolios. An interview protocol was prepared to match the research objectives and research questions in this study. The interview 
questions were semi-structured to allow other questions to emerge during the interviewing process so that additional ideas could be explored. Examples of the open ended questions are: What was your motivation for joining politics? What does ethical leadership mean to you in the context of politics? Do you think public trust in politicians and political institutions has been declining? Why? Do you think ethics matters in politics? Why and how? In total, 121 interviews were conducted, enough to confirm the adequacy and quality of data to support the study's conclusions, and show that further data collection and/or analysis were unnecessary. Most of the interviews were recorded (and transcribed) and field (or interview) notes were taken with permission from the interviewees. The anonymity of councillors and councils was promised in order to encourage their participation, and this anonymity is preserved here.

The councils and councillors were selected primarily using a purposive sampling technique (Pettigrew, 1990) in order to incorporate a diverse context for leadership likely to bear on patterns of behaviour and actions - thus mitigating the problem of sampling bias. It also helped to build a logical chain of evidence, increasing internal and external construct validity (Eisenhardt, 1989). The councils were selected with due consideration to factors such as type, size (population), leadership, political make up and location of the council. For example, different types of councils such as Unitary authorities, County councils, District councils, London boroughs and Metropolitan district councils from across the UK were selected to represent different types of political control and make-up such as controlled by Conservatives, Labour, Liberal Democrats, SNP, independent councillors and coalition government. In selecting councillors, a number of political and demographic factors such as party affiliation, level of leadership position and gender were considered. To achieve balance, extra effort was made to increase participation of Conservative (party) and female councillors. In total, 121 councillors (4 of them submitted their written responses to the interview questions) from 65 local authorities participated in the study. Although the sample size is not statically representative, it covers a diverse range of councillors (approx. $0.5 \%$ of councillors of principal councils) and councils (approx. 16\% of principal councils) in the UK. The profile of the councillors is presented in Table 1.

Data collection followed a three-stage sequential approach with some overlaps between them. In the first phase, several interviews with selected councillors across the UK were conducted in order to gain insights and refine the data collection procedure. In the second phase, the focus was on 11 purposely selected councils to gain more insights and find answers to the research questions. In the third phase, numerous interviews with purposely selected councillors from across the UK were carried out in order to triangulate the data collected. Triangulation strengthened the persuasiveness of the data by enhancing the perceived validity of our findings, and was useful for confirming the accuracy of the data and corroborating our conclusions.

Data analysis consisted of a three-stage process. In the first stage, a thematic framework was developed through an iterative process of dialogue between the data and the literature (Eisenhardt \& Graebner, 2007). In the second stage, data were 
Table 1 Profile of the informants (Councillors)

\begin{tabular}{|c|c|c|}
\hline Factors & Characteristics & Informants (total 121) \\
\hline \multirow[t]{2}{*}{ Gender } & Female & $26 \%$ \\
\hline & Male & $74 \%$ \\
\hline Age & Average (in years) & 54 \\
\hline $\begin{array}{l}\text { Experience as a } \\
\text { councillor }\end{array}$ & Average (in years) & 10 \\
\hline \multirow[t]{3}{*}{ Position } & $\begin{array}{l}\text { Mayor/deputy mayor, council leader/deputy leader, party } \\
\text { group leader/deputy leader }\end{array}$ & $25 \%$ \\
\hline & $\begin{array}{l}\text { Cabinet lead, deputy/assistant cabinet lead, secretary, chair/ } \\
\text { vice chair of committees, whip/deputy whip }\end{array}$ & $42 \%$ \\
\hline & Councillor/Alderman without portfolio & $33 \%$ \\
\hline \multirow[t]{7}{*}{ Party affiliation } & Conservative & $31 \%$ \\
\hline & Green & $2 \%$ \\
\hline & Independent & $4 \%$ \\
\hline & Labour & $41 \%$ \\
\hline & Liberal Democrats & $14 \%$ \\
\hline & Others & $4 \%$ \\
\hline & SNP & $3 \%$ \\
\hline \multirow[t]{4}{*}{ Location } & England & $83 \%$ \\
\hline & Northern Ireland & $3 \%$ \\
\hline & Scotland & $8 \%$ \\
\hline & Wales & $6 \%$ \\
\hline \multirow[t]{5}{*}{ Education } & Doctorate degree & $2 \%$ \\
\hline & Master's degree & $40 \%$ \\
\hline & Bachelor's degree & $37 \%$ \\
\hline & Professional/vocational qualification & $9 \%$ \\
\hline & A-levels (or equivalent) or less & $13 \%$ \\
\hline \multirow[t]{5}{*}{ Religion } & Christianity & $48 \%$ \\
\hline & Hinduism & $3 \%$ \\
\hline & Islam & $6 \%$ \\
\hline & Judaism & $2 \%$ \\
\hline & No religion & $41 \%$ \\
\hline \multirow[t]{5}{*}{ Ethnicity } & Asian/Asian British & $9 \%$ \\
\hline & Black/African/Caribbean/ Black British & $2 \%$ \\
\hline & White English/Welsh/ Scottish & $80 \%$ \\
\hline & White Irish & $5 \%$ \\
\hline & Mixed/other ethnic group & $4 \%$ \\
\hline
\end{tabular}

109 informants disclosed their age and religion

112 informants disclosed their education and ethnicity

116 informants disclosed duration of their experience as a councillor

coded and categorized using interpretative strategies, combined with open coding and axial coding (Corbin \& Strauss, 2007). This was followed by comparing and 
hence drawing similarities and differences, leading to categorization of recurrent patterns (Leitch et al., 2010).

\section{Findings and Analysis}

The study has found evidence in support of a decline in public trust in political leaders and government. The level of trust varies over time across people (demographic groups). However, across the UK, a large majority of the participant local councillors (who are close to local people) perceive that the trend is downward. Interestingly, there are no significant variations among the respondents related to their demographic profile, which may be partly due to a relatively small sample size. A deputy leader of a party group says: “...collective politicians where people have little respect for, but individual politicians, when they meet them - in my experience people genuinely like them and respect them." However, a leader of a party group has a different experience: "... when you speak to people on the door steps ... the perception that you are all the same. It does not matter whether you are ... whatever, you are all the same."

As to the question of why the level of public trust in political leaders is going down, Brexit is at the heart of the recent falling. However, when asked, a vast majority of the local politicians in the study thought that unethical political leadership behaviour were part-causes of the low level of public trust. A leader of a party group eloquently summarises:

We had a number of scandals over the years things like MPs' expenses scandals where people claimed money they should not have done, all those kind of things. And, they do tend to create a perception that politicians are there for themselves not for the wider good. People of the country promised a referendum and they were told their views would be binding. And, since then we had a decisive vote to leave European Union and it has not been enacted. So, then when you get into a situation where politicians promised to deliver something and they don't and completely break their promise all together. I think it can create a really bad situation where there is a real disconnection between public and people who are here to serve them.

Nevertheless, politicians are just humans. Naturally they sometimes (hopefully not very often) err. When asked, a vast majority of respondents said they joined politics with the best of intention (public service). Sometimes people end up acting wrongly if the system is not geared to preventing it. Politics is a social phenomenon, no different from other walks of life. Unscrupulous behaviour cannot be completely eliminated either from politics or from other parts of the society. However, political leaders, with the mandate to govern the community, have both moral and legal obligation not only to improve their own conducts but also to create (and implement) a system that is conducive for others to conduct themselves well. The answer to 
the question of how, which is the focus of the study, is discussed in the following subsections: The Regulatory Framework, Being a Moral Person, and Being a Moral Leader.

\section{In the Context of the Regulatory Framework}

A large majority of the local politicians who participated in the study think that the code of conduct for councillors helps them to understand what the council and the public expect from them. It also gives the public a means to challenge politicians. A chair of an Overview and Scrutiny Committee who has been a councillor for 30 years states: "I lived under a situation where there was not a code of conduct and now there is one. There is a qualitative difference." The code has created awareness for many, though for some it is just another documented set of rules.

Apart from the code of conduct, there is also a set of party rules that controls the conducts of councillors. It is useful to have one, yet it may not be an ideal mechanism where politicians are judging themselves. Some councillors have little confidence in party disciplinary process because it was flawed and manipulated by political leaders. Party leadership intervened for political reasons and there were no punishments for wrongdoings. This created dilemmas for others who wanted to abide by the rules. Both politicians and public seem to have relatively more confidence in the monitoring officer, independent standard committee, commissioner or ombudsman that they will assess any breach of code or rules properly and fairly-partly because, to some extent, it is taken out of the hands of politicians. Nonetheless, there were occasions when the system was exploited-politicians complained against their rivals, and the public against politicians for political and personal reasons.

For some, the code is not as clear as they would like it. They feel it requires a bit of subjective interpretation, and has not helped much in terms of improving behaviour among councillors, or between councillors and others, or behaviour in social media. Nevertheless, neither the code nor rules can encompass every eventuality. Also, like any other set of rules and regulations, "... you could have the most perfect code of conduct in the world on paper and if it is not implemented properly then it is next to useless" (a deputy Mayor). Sometimes there are problems with how the code is overseen and managed. And how one interprets the code is also a question of leadership. Sometimes people may try to bend the code and then get away with it if the whip, leader or monitoring officer is not strong enough. Sometimes people who are in charge are afraid to challenge others when they think it may rebound on them. Sometimes, for some people, the code is toothless because there is limited provision for sanctions against councillors (elected representatives). Equally, sometimes there is not sufficient reward/incentive for good conduct.

When asked, a large majority of respondents thought that induction/training for the code and other ethical issues such as diversity, equality and public values is useful, particularly for newly elected councillors. It might be even more helpful for those who are new to politics if the induction/orientation (or ethical screening) takes place during the process where the party leadership selects the candidates for election. 
To sum up, and move on to the moral framework, in the words of a leader of a council:

I certainly think they are helpful and it is better to have a code of conduct and a set of rules than not. But I also like to think that I and majority of councillors would have the right motivation and take the decision that were consistent with the motivation even if the code of conduct did not exist. But, I think it is helpful to have one, but it is not something I refer to very often or I refer to help my decision. It is my belief and moral framework that guide the majority of time.

\section{Being a Moral Person}

When asked, a vast majority of informants believe that ethics matters in politics. "It is one's personal make up that dictates the type of person we are - how we act in public ... how we act as a councillor" (a deputy leader of a council). Sometimes, like others, politicians find themselves in dilemma. "People do not mind if you are confused as long as they feel that they trust you" (a councillor). Everybody has his (or her) own view on what is right and what is wrong. Yet, we have a moral obligation to treat others with a certain degree of respect even when we disagree with each other.

Trust is a key component of political capital (Kjaer, 2013). Trust erodes when our words and actions do not accord. It significantly affects trust when politicians promise the public something in order to get themselves elected, and it then becomes obvious that they can't or won't do what they said they would. A vast majority of councillors thought, when asked, that sometimes politicians over-promise to get elected or re-elected and then fail to deliver, which is not ethical and has a negative impact on public trust. "I think sometimes politicians take a calculated view of ... what they are going to promise and whether they can get out of that promise, how effective that promise will be in getting them voted and how they can sort of square out that promise later" (a councillor). Sometimes, politicians vie for public support against each other because of rivalry within and between the parties. So, a party group leader suggests:

You have got to actually do what you say you are going to do. You know you cannot be elected and then go against what you said you were going to do. So, I would like to see a lot more honesty from politicians and I would like to see a manifesto setting out clearly what a party will do. I accept there are times when situations have changed and new information has come to light and you have to change the course you are on, and in that situation politicians need to engage with electorates and explain to people that things have changed instead of pretending that they have not changed and that was the plan all along.

Yet, the problem (apparently) with saying that is that you may lose the vote, or it may bring an end to your leadership, which presents an ethical dilemma for many politicians. It is still important to tell people things as they are rather than what they want to hear. Occasionally, there are tensions between being effective and doing 
the right thing. Some politicians believe sometimes they need to lower their moral standards for practical reasons. Some thinks if you do not have right values you should not be a councillor. Others think you can be principled and moderate in your view at the same time (following the middle path). When a leader has competence (right set of skills to do the job) combined with honesty he may become a powerful force for a real positive change in politics and the wider society.

\section{Being a Moral Leader}

When asked, a vast majority of councillors believed political leaders have important roles to play in influencing the conducts of their followers and creating an ethical culture in the local authority. Local politicians are quite visible in the community because of their close proximity to the local people, who can easily see them and observe their activities and understand whether they are behaving rightly or not. The public, council officers and fellow councillors, particularly new councillors, may recognise and copy senior politicians' good behaviour. Leaders may lose respect from them if their behaviours are not appropriate. A recently elected councillor says: "Certainly when you are new you look at more experienced people and leaders, how they do things." There is a perception that if leaders are behaving properly then people will behave properly; if leaders aren't, why should they? Hence, "senior politicians should abide by the rules and also encourage their supporters to abide by the rules" (a deputy Mayor).

Role modelling (setting a good example) is an important component of ethical leadership. It requires sincere actions; not just rhetoric, which people will eventually see through. Ethical leaders set the tone at the top and challenge those who are not behaving ethically. A deputy leader of a council observes: "We have had incidents where candidates have behaved inappropriately and the leadership has taken a firm stance on those issues and acted in my view appropriately on them and the group has supported those actions." Followers and supporters are likely to behave ethically by observing that good behaviour is rewarded by offering appropriate positive incentives, and bad behaviour is punished by offering negative incentives through due disciplinary process. However, in councils where there is no opposition party (one party has all the seats-a monopoly power), there are examples of party disciplinary process being manipulated. In those cases, it may not be possible to rely on the leadership. There needs to be a robust set of rules, code, disciplinary process and a controlling mechanism. Yet if this system is not implemented properly it may become useless. A moral leader sets good examples and challenges people who behave unethically. A party group leader explains:

If an individual councillor is going to do something then it is not necessarily the fault of the group leader but it is certainly the responsibility of the group leader to take a firm line against those actions and to ensure that they are dealt with appropriately. Because if you don't, it sends out completely the wrong message to the public. It may be construed as acceptance of the behaviour 
and of course it sends out a message to others that it is acceptable to do those things.

Leaders (across levels) should do what they say they will do otherwise they may lose their moral credibility. "It is also up to the party organization (leadership) to say, 'hey, don't say you are going to deliver something you cannot deliver, you have not got the money, ability or power to do that. So don't say you can'" (a cabinet lead). Sometimes, due to changing circumstances, it might not be possible to fulfil a commitment, but that needs to be honestly explained and communicated to the public.

To sum up, the ethical political leadership process begins with striving to become a moral person, and then a moral leader. In the words of a councillor: "I think it means just doing what you say you will do, not lying, not misleading people, but trying to represent people as best as you can." If you continually do that over a long period of time most people are likely to trust you, even during difficult times.

\section{Discussion}

Public trust in political leaders is crucial for effective functioning of a democratic government because otherwise public is likely to be disengaged and disenchanted with the democratic system. The study uses qualitative analysis to explain processes by which different elements (code of conduct, moral person and moral leader) of ethical leadership have an effect on public trust. Codes of ethics appears to be insufficient to achieve changes without other social processes. The study establishes how moral person dimension has an influence on moral leader dimension of ethical leadership. The study finds that ethical leadership is not just about complying with the codes (and rules), personal moral framework is also important to act as a role model, by setting an example and a tone at the top. The findings of the study demonstrate the explanatory power of moral leadership, explaining how ethical leaders may combine personal moral framework and formal regulatory processes with social learning processes.

The concept of ethical political leadership extends work by Morrell and Hartley (2006a, b) by integrating ethics into political leadership. Theoretically, this article supports social exchange (Bandura, 1977, 1986) and social learning (Blau, 1964) theory, which explains how ethical political leadership practices can positively affect public trust in political leaders. The study also highlights that our ethical framework (set of moral values) should guide our behaviour. Of course, the proponents of virtue ethics, deontologist and consequentialist (including utilitarian) ethics will have their own views of what is right and what is wrong. Yet, there must be some core ethical values to be applied consciously and wisely.

The key findings of the study are that ethical leadership matters in politics and ethical leadership practices such as being truthful, keeping promises, caring for others and engaging with public can help restore some of the lost trust. Political leaders can influence the behaviour of their colleagues and citizens through role modelling (setting good examples), particularly by encouraging those who are new to politics 
to emulate good behaviour. Public evaluation of the characteristics of political leaders such as honesty, truthfulness, keeping promises, fairness and concern for others is likely to affect public trust.

This study recommends a number of measures that political leaders (at local, national and international level) may adopt to promote ethical leadership in politics. Senior political leaders should set the tone at the top and challenge and punish those who are not behaving ethically. Ethical training helps to maintain awareness, particularly for those who are new to politics. For some councillors, self-training (or self-learning) may help, for others training (or mentoring) programme may be more helpful. However, training should not be just a compliance exercise, rather it should help the participants to realise the value of serving others, and ignite their moral values and inner purposes. Ethical political leadership may also develop and implement a system of tighter ethical screening in the process of selecting candidates, and it would be helpful if their induction to the code were to take place during this process. Political leadership may also develop and implement a system that will encourage, reward and support ethical leadership practices.

\section{Conclusion}

The primary objective of the study is to understand how ethical leadership practices can help to restore public trust in political leaders and government. In doing so, a qualitative approach was used and local political leaders across the UK were interviewed. The findings of the study confirm that public trust in political leaders and government is declining. This is partly caused by unethical leadership behaviour. The solution lies mainly in the hands of the politicians themselves. The study has found that while having a code of conduct is useful, it is the politician's personal moral framework that has a more profound influence on how they generally act. Being a moral person, an ethical political leader sets good examples of behaviour, sets the tone at the top and challenges those who do not behave ethically, as well as encourages, supports and rewards those who perform and conduct themselves well. The level of public trust in political leaders is likely to increase gradually when politicians continue to tell the truth, keep their pledges (or explain to the public why they have been unable to do so), engage with the citizens and serve them to the best of their abilities over a long period of time.

While this study provides evidence that ethical leadership practices may help to restore public trust in political leaders and government, it is difficult to be certain about the causal linkage between ethical leadership behaviour and trust in leaders. This is because every study is time and context bound (Grbich, 2012). Yet, the study provides us with insights into how ethical political leadership practices may help to gradually restore some of the lost trust. There might be some response, recall and interpretation bias although the issue has been addressed by aggregating data collected from multiple informants with a diverse background across the UK. Future research may conduct a longitudinal 
study in order to examine the effect of ethical leadership practices on public trust in political leaders over a long period. This study includes a number of selected councils and councillors in the UK, providing profitable research opportunities to determine whether its results hold in other local, national or international contexts.

\section{Declarations}

Informed Consent Informed consent was obtained from all individual participants included in the study.

Ethical Approval All procedures performed in studies involving human participants were in accordance with the ethical standards of the institutional and/or national research committee and with the $1964 \mathrm{Hel}$ sinki declaration and its later amendments or comparable ethical standards.

\section{Conflict of Interest None.}

Open Access This article is licensed under a Creative Commons Attribution 4.0 International License, which permits use, sharing, adaptation, distribution and reproduction in any medium or format, as long as you give appropriate credit to the original author(s) and the source, provide a link to the Creative Commons licence, and indicate if changes were made. The images or other third party material in this article are included in the article's Creative Commons licence, unless indicated otherwise in a credit line to the material. If material is not included in the article's Creative Commons licence and your intended use is not permitted by statutory regulation or exceeds the permitted use, you will need to obtain permission directly from the copyright holder. To view a copy of this licence, visit http://creativecommons.org/licen ses/by/4.0\%.

\section{References}

Bandura, A. (1977). Social learning theory. Prentice Hall.

Bandura, A. (1986). Social foundations of thought and action: A social cognitive theory. Prentice Hall.

Beerbohm, E. (2015). Is democratic leadership possible? American Political Science Review, 109(4), 639-652.

Beshi, T. D., \& Kaur, R. (2020). Public trust in local government: Explaining the role of good governance practices. Public Organization Review, 20, 337-350.

Blau, P. M. (1964). Exchange and power in social life. Wiley.

Brown, M., Treviño, L. K., \& Harrison, D. A. (2005). Ethical leadership: A social learning perspective for construct development and testing. Organizational Behavior and Human Decision Processes, 97(2), 117-134.

Citrin, J., \& Stoker, L. (2018). Political trust in a cynical age. Annual Review of Political Science, 21(1), $49-70$

Committee on Standards in Public Life. (2019). Local Government Ethical Standards. CSPL- UK. https:// www.gov.uk/government/publications/local-government-ethical-standards-report.

Corbin, J., \& Strauss, A. (2007). Basics of qualitative research: Techniques and procedures for developing grounded theory. Sage.

Dinh, J. E., Lord, R. G., Gardner, W. L., Meuser, J. D., Liden, R. C., \& Hu, J. (2014). Leadership theory and research in the new millennium: Current theoretical trends and changing perspectives. Leadership Quarterly, 25(1), 36-62.

Downe, J., Cowell, R., Chen, A., \& Morgan, K. (2013). The determinants of public trust in English local government: How important is the ethical behaviour of elected Councillors? International Review of Administrative Sciences, 79(4), 597-617. 
Elderman Trust Barometer. (2019a). Elderman Trust Barometer 2019 - A Disunited Kingdom. London. https://www.edelman.co.uk/sites/g/files/aatuss301/files/2019-04/Edelman-Trust-Barometer-UK2019.pdf

Elderman Trust Barometer. (2019b). Elderman Trust Barometer 2019 - Global Report. London. https:// www.edelman.com/sites/g/files/aatuss191/files/2019-02/2019_Edelman_Trust_Barometer_Global_ Report.pdf

Eisenhardt, K. M. (1989). Building theories from case study research. Academy of Management Review, 14(4), 532-550.

Eisenhardt, K. M., \& Graebner, M. E. (2007). Theory building from cases: Opportunities and challenges. Academy of Management Journal, 50(1), 25-32.

Flick, U. (2002). An introduction to qualitative research. Sage.

Fry, L. W. (2003). Toward a theory of spiritual leadership. Leadership Quarterly, 14(6), 693-727.

Grbich, C. (2012). Qualitative data analysis: An introduction. Sage.

Hassan, S. (2015). The importance of ethical leadership and personal control in promoting improvementcentered voice among government employees. Journal of Public Administration Research and Theory, 25(3), 697-719.

Hassan, S., Wright, B. E., \& Yukl, G. (2014). Does Ethical leadership matter in government? Effects on organizational commitment, absenteeism, and willingness to report ethical problems. Public Administration Review, 74(3), 333-343.

Kjaer, U. (2013). Local political leadership: the art of circulating political capital. Local Government Studies, 39(2), 253-272.

Leach, S., \& Wilson, D. (2002). Rethinking local political leadership. Public Administration, 80(4), 665-689.

Leitch, C. M., Hill, F. M., \& Harrison, R. T. (2010). The philosophy and practice of interpretivist research in entrepreneurship: Quality, validation and trust. Organizational Research Methods, 13(1), 67-84.

Luthans, F., \& Avolio, B. J. (2003). Authentic leadership: A positive development approach. In K. S. Cameron, J. E. Dutton, \& R. E. Quinn (Eds.), Positive organizational scholarship (pp. 241-261). Berrett-Koehler.

March, J. G., \& Olsen, J. P. (2004). The logic of appropriateness. ARENA Working Papers (9). Centre for European Studies, University of Oslo.

Morrell, K., \& Hartley, J. (2006a). A model of political leadership. Human Relations, 59(4), 483-504.

Morrell, K., \& Hartley, J. (2006b). Ethics in leadership: The case of local politician. Local Government Studies, 32(1), 55-70.

Mozumder, N. A. (2018). A multilevel trust-based model of ethical public leadership. Journal of Business Ethics, 153(1), 167-184.

Ng, T. W., \& Feldman, D. C. (2015). Ethical leadership: Meta-analytic evidence of criterion-related and incremental validity. Journal of Applied Psychology, 100(3), 948-965.

Osborn, R. N., Hunt, J. G., \& Jauch, L. R. (2002). Toward a contextual theory of leadership. Leadership Quarterly, 13(6), 797-837.

Pettigrew, A. M. (1990). Longitudinal field research on change: Theory and practice. Organization Science, 1(3), 267-292.

Rose, R., \& Wessels, B. (2019). Money, sex and broken promises: Politicians' bad behaviour reduces trust. Parliamentary Affairs, 72(3), 481-500.

Rousseau, D. M., Sitkin, S., Burt, R. S., \& Camerer, C. (1998). Not so different after all: A cross-discipline view of trust. Academy of Management Review, 23(3), 393-404.

Van Wart, M. (2013a). Administrative leadership theory: A reassessment after 10 years. Public Administration, 91(3), 521-543.

Van Wart, M. (2013b). Public-sector leadership theory: An assessment. Public Administration Review, 63(2), 214-228.

Walzer, M. (1973). Political action: The problem of dirty hands. Philosophy \& Public Affairs, 2(2), $160-180$.

Publisher's Note Springer Nature remains neutral with regard to jurisdictional claims in published maps and institutional affiliations. 